\title{
Using Food Waste Biomass as Effective Adsorbents in Water and Wastewater Treatment for $\mathrm{Cu}(\mathrm{II})$ Removal
}

\author{
Muharrem Ince $^{a, *}$, Olcay Kaplan Ince ${ }^{\mathrm{b}}$, Eren Asam $^{\mathrm{b}}$, and Ali Önal \\ ${ }^{a}$ Munzur University, Faculty of Engineering, Department of Chemical Engineering, \\ 62000 Tunceli, Turkey \\ ${ }^{b}$ Munzur University, Faculty of Engineering, Department of Food Engineering, \\ 62000 Tunceli, Turkey
}

\section{INTRODUCTION}

Pollution of the environment is of great concern, in particular from the toxic and hazardous effects of heavy metals such as copper $(\mathrm{Cu})$, lead $(\mathrm{Pb})$, and cadmium $(\mathrm{Cd})$. These metals are highly soluble and are found in microelectronics, wood, and water. They are released into aqueous systems and soil and air, and are released through a variety of sources such as metal plating and smelters, eluents from plastics, mining, textiles, paint industry, preservative-producing industries, and use of fertilizers (1).

Along with arsenic (As) and mercury $(\mathrm{Hg}), \mathrm{Cu}$ is recognized as the highest relative mammalian toxic substance. $\mathrm{Cu}$ is also not biodegradable and tends to accumulate in living organisms causing various health hazards (2- 5). Excessive levels of heavy metals have been linked with a wide range of health conditions such as cancer, especially lung cancer, birth defects, skin disease, hypertension, bone lesions, lung insufficiency, and damage to the nervous system (6-8). The World Health Organization (WHO) has mandated international regulations to reduce the levels of diffeerent compounds in wastewater $(9,10)$. Because of their harmful effects on human health and the flora and fauna of water bodies, many health organizations around the world have been controlling the discharge of heavy metals into the aquatic environment by reducing the concentrations in

*Corresponding autbor.

E-mail: mubarremince@munzur.edu.tr

Tel: +904282131794

Fax: +904282131624

\begin{abstract}
The present study investigated $\mathrm{Cu}(\mathrm{II})$ ion adsorption onto banana peel, chestnut shell, and tea leaf waste in aqueous medium under different experimental conditions. Batch adsorption studies were carried out with various $\mathrm{Cu}$ (II) concentrations as well as the influence of process parameters such as $\mathrm{pH}$, contact time, and adsorbent amount on the removal of copper, and the optimum conditions for maximum removal of copper from an aqueous solution. These food waste biomass adsorbents were applied to mineral water and industrial wastewater samples and the copper removal potentials were compared.

The nature of the adsorbents and metal ion interactions was examined by the fourier transform infrared spectroscopy (FTIR) technique. The adsorption data were obtained by using the Langmuir model showing maximum adsorption capacity of banana peel, chestnut shell, and tea leaf waste at $1.94 \mathrm{mg} \mathrm{g}^{-1}$, $2.25 \mathrm{mg} \mathrm{g}^{-1}$, and $3.36 \mathrm{mg} \mathrm{g}^{-1}$, respectively. Copper was determined by flame atomic absorption spectrometry.
\end{abstract}

water to less than $5 \mathrm{mg} \mathrm{L}^{-1}$ (U.S. EPA) (11). The concentration limits (international standards) of hazardous waste-containing metals are different. For example, copper at 2.5 $\mathrm{mg} \mathrm{kg}^{-1}$, nickel at $20 \mathrm{mg} \mathrm{kg}^{-1}$, cadmium at $1 \mathrm{mg} \mathrm{kg}^{-1}$, and mercury at $0.2 \mathrm{mg} \mathrm{kg}^{-1}$ in water $\left(\mathrm{mg} \mathrm{L}^{-1}\right)$ or soil $\left(\mathrm{mg} \mathrm{kg}^{-1}\right)$, respectively $(1,12)$. In order to remove metals in contaminated waters, a wide variety of methods including solvent extraction, ion exchange, osmosis, membrane filtration, chemical precipi- tation, biosorption, especially adsorption, have been tested. However, in general the adsorption technique has become the preferred method for removing hazardous heavy metals from wastewater because of simplicity, cost-effectiveness, non-toxicity, chemical and mechanical stability, and local availability $(8,13-16)$. In addition, the adsorption technique is a simpler and cost-effective technique compared to other methods.

Many factors affect the efficiency of adsorption, including polarity, distribution, surface area, pore size, and type of adsorbent (17-19). In recent years, several studies have undertaken to remove heavy metals from wastewater using methods other than low-cost and ecofriendly materials. These cost-effective materials range from industrial by-products or waste, for example, to widely used adsorbents for adsorption of metal ions such as waste rubber tires (20), activated carbon (21), clay minerals (22), biomaterials (23), industrial solid wastes $(24,25)$, zeolites $(26,27)$, agricultural products such as coconut husks, rice straw, wool, nut wastes, and peat moss (28-31). An adsorption technique using natural adsorbents, especially food waste, is often regarded as the most appropriate method for wastewater treatment $(26,32-35)$.

Although a large number of studies have been reported by different researchers about copper adsorption on different food wastes, no studies have been reported using chestnut shell, banana peel, and tea leaf waste.

In the present study, an attempt has been made to develop a low- 
cost and eco-friendly adsorbent system consisting of food waste for the removal of copper from aqueous solutions using chestnut shell, banana peel, and tea leaf waste. They have no utility and therefore do not cause environmental degradation. These natural materials were examined by varying experimental conditions such as solution $\mathrm{pH}$, contact time, adsorbent dose for the removal of $\mathrm{Cu}$ (II) from aqueous systems. The experimental data were correlated to different adsorption isotherm models and the corres- ponding parameters were determined. These parameters are considered fundamental for other research studies.

Banana peel, chestnut shell, and tea leaf waste contain the carboxylic and hydroxyl groups and are, therefore, low cost, attractive, and effective adsorbents for the removal of copper from wastewater. Although classical and conventional methods of studying a process by maintaining other factors involved at an unspecified constant level does not depict the combined effect of all the factors involved. At the same time, this method is also time-consuming and requires a number of experiments to determine optimum levels for $\mathrm{Cu}$ (II) removal. But other disadvantages do not matter since they are environmentally friendly and food waste materials are used as natural adsorbents.

\section{EXPERIMENTAL}

\section{Chemicals}

Copper nitrate, sodium hydroxide, hydrochloric acid, sodium citrate monohydrate, sodium dihydrogen phosphate, sodium tetraborate, and nitric acid were obtained from Merck (Darmstadt, Germany). All chemicals used were of analytical grade.

\section{Preparation of Adsorbents}

The bananas and chestnuts were purchased at a local market in
Tunceli and solid tea leaf waste was provided from use at private homes, then washed with tap and distilled water to remove any dirt, and peeled when appropriate. All adsorbents were oven-dried at $60^{\circ} \mathrm{C}$ until constant weight, ground in a blender, sieved to particles of $<120$ mesh, and stored in polyethylene bags at room temperature until use.

\section{Preparation of Standard Solutions}

A stock solution of $1000 \mathrm{mg} \mathrm{L}^{-1}$ $\mathrm{Cu}(\mathrm{II})$ was prepared by dissolving an accurate quantity of $\mathrm{Cu}\left(\mathrm{NO}_{3}\right)_{2}$ in distilled water. Other concentrations varying from 1 to $400 \mathrm{mg} \mathrm{L}^{-1}$ were prepared from stock solutions by dilution.

\section{Batch Adsorption Studies and FAAS Instrumental Conditions}

In this investigation, all adsorption experiments were performed in Erlenmeyer flasks containing $\mathrm{Cu}(\mathrm{II})$ synthetic solutions and adsorbents of $<120$ mesh adsorbent particle size added to the solutions. The effects of initial metal ion concentration (5-100 $\left.\mathrm{mg} \mathrm{L}^{-1}\right), \mathrm{pH}$ (2-9) and contact time (10 to $180 \mathrm{~min}$ utes) were studied at room temperature. The $\mathrm{pH}$ was adjusted using hydrochloric acid and sodium hydroxide. A Jenco 6173 digital pH meter (Shanghai Jenco Electronics, Shanghai, P.R. China) was used for the $\mathrm{pH}$ measurements.

The adsorbent was separated from the samples by filtering and the filtrate was analyzed for $\mathrm{Cu}$ concentration using a PerkinElmer ${ }^{\circledR}$ AAnalyst $^{\mathrm{TM}} 800$ atomic absorption spectrometer (PerkinElmer, Inc., Shelton, CT, USA). The instrumental operating conditions are listed in Table I. Each experiment was carried out in triplicate and the average results are presented.

\section{Characterization of Adsorbent Using FTIR Sprectra}

Fourier transform infrared (FTIR) spectra of the pretreated banana

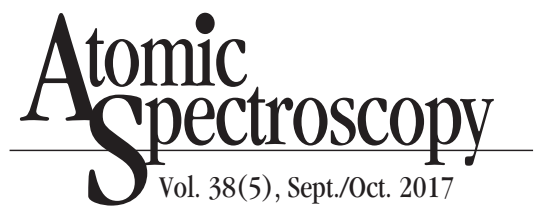

peel, chestnut shell, and tea leaf waste were compared with the FTIR of their spiked samples with $\mathrm{Cu}$. The spectra were recorded in the frequency range of 4000-500 $\mathrm{cm}^{-1}$ using a Thermo Nicolet iS10 FTIR spectrophotometer (Thermo Scientific, USA). The instrumental operating conditions are listed in Table II. The samples were analyzed with Attenuated Total Reflectance (ATR) using diamond crystal.

\section{RESULTS AND DISCUSSION}

\section{Effect of pH}

For $\mathrm{pH}$ optimization, about $0.25 \mathrm{~g}$ of adsorbent was added to $15 \mathrm{mg} \mathrm{L}^{-1}$ Cu(II) solutions, then placed on a Radwag AS 220/C/2 (Radwag Balances \& Scales, Poland) magnetic stirrer for 45 minutes. The $\mathrm{pH}$ was optimized in the 2-9 range. Citrate, phosphate, and borate buffers were used for the different $\mathrm{pH}$ ranges of $2-5,6-7$, and 8-9, respectively. It was observed that adsorption of copper was maximum for banana peel, chestnut shell, and tea leaf waste at $\mathrm{pH} 4,6$, and 5, respectively. The results are shown in Figure 1. The changing $\mathrm{pH}$ and adsorption values can be explained due to the competition between the metal

TABLE I

Instrumental Operating Conditions of AAnalyst ${ }^{\mathrm{TM}} 800$ FAAS

\begin{tabular}{cc}
\hline Parameters & Values \\
\hline Wavelength & $324.8 \mathrm{~nm}$ \\
HCL current & $30.0 \mathrm{~mA}$ \\
Flow rates: & \\
Air & $17 \mathrm{~L} \mathrm{~min}^{-1}$ \\
Acetylene & $2 \mathrm{~L} \mathrm{~min}^{-1}$ \\
Slit width & $0.7 \mathrm{~nm}$ \\
\hline
\end{tabular}

TABLE II

Instrumental Parameters for FTIR Analysis

Wavelength range $\quad 4000-500 \mathrm{~cm}^{-1}$ Sample to $\mathrm{KBr}$ mass ratio $\quad 1: 100$ Spectral resolution $\quad 4 \mathrm{~cm}^{-1}$ Type of crystal Diamond 
ions and protons for the same functional groups which results in a higher electrostatic attraction between the metal and the surface.

There are a large number of studies for the use of adsorbents, but different results were reported. Yao et al. (36) studied the biosorption of $\mathrm{Cu}$ (II) onto chestnut shell using a batch experiment system. Different isotherm models such as the Langmuir model were evaluated. According to their results, the equilibrium data agreed well with the Langmuir and Redlich-Peterson isotherm models. As a result, the adsorption capacity of chestnut shell for $\mathrm{Cu}$ (II) was determined and found to be $12.56 \mathrm{mg} \mathrm{g}^{-1}$ at room temperature using a $\mathrm{pH}$ of 4 to 6 . They determined the maximum value of metal retention and found that there was a decrease in the capacity of retention with a decreasing pH from 4 to 2 (36). In an another study (7), tea waste was used as the adsorbent and the maximum adsorption of the $\mathrm{Ni}(\mathrm{II})$ ions was obtained at $\mathrm{pH}$ 4.0. Jiang et al. (37) found that the adsorption of $\mathrm{Ni}(\mathrm{II})$ increased with an increase in $\mathrm{pH}$ from 2.0 to 8.0 onto kaolinite clay.

\section{Contact Time Studies}

The influence of contact time on the adsorption of $\mathrm{Cu}$ (II) on banana peel, chestnut shell, and tea leaf waste was evaluated from 10 to 180 minutes (Figure 2). The best contact time for banana peel was 30 minutes, for chestnut shell $90 \mathrm{~min}$ utes, and for tea waste 30 minutes.

Black and green tea leaves were used as the adsorbent for $\mathrm{Pb}$ removal from aqueous solution by Zuorro and Lavecchia (38). They mixed about $0.5 \mathrm{~g}$ of tea leaves with $0.1 \mathrm{~g} \mathrm{~L}^{-1} \mathrm{~Pb}$ solution. At the temperature of 25 or $40{ }^{\circ} \mathrm{C}$, the contact time was set to 2 hours. A comparison of adsorbents such as used tea leaves and coffee grounds with regard to $\mathrm{Pb}$ removal efficiency showed that they behaved quite similar. Their average adsorption capacity was $10.81 \pm 0.42 \mathrm{mg} \mathrm{g}^{-1}$ (at $40{ }^{\circ} \mathrm{C}$ ) and $10.99 \pm 0.11 \mathrm{mg} \mathrm{g}^{-1}$ (at $25^{\circ} \mathrm{C}$ ), respectively. According to another study result, the influence of contact time on the adsorption of $\mathrm{Ni}$ (II) on different low-cost and natural adsorbents such as tea waste and egg shell was evaluated from 10 to180 minutes. The contact time was fixed at 45 minutes for tea leaf waste and egg shell (8).

\section{Adsorbent Amount Study for $\mathrm{Cu}($ II)}

The effect of adsorption of copper ions on the amount of banana peel, chestnut shell, and tea leaf waste (from 0.1 to $1.0 \mathrm{~g}$ ) was studied using $100-\mathrm{mL}$ solutions with an optimum stirring time and $\mathrm{pH}$. The adsorbed $\mathrm{Cu}(\mathrm{II})$ amount increased with an increase in the amount of banana peel from $0.1 \mathrm{~g}$ to $0.5 \mathrm{~g}$, while the optimum amount of adsorbent for maximum adsorbed copper on both chestnut shell and tea leaf waste was $0.25 \mathrm{~g}$. The adsorption efficiency of $\mathrm{Cu}(\mathrm{II})$ onto the three natural adsorbents is shown in Figure 3. During the adsorption reaction, many reasons such as incomplete saturation of the adsorption site and particle interaction can increase the amount of adsorbent used against a decline in $\mathrm{q}_{\mathrm{e}}$. A particle interaction and aggregation can cause a reduction in the total surface area of the adsorbent (39).

Ince et al. (13) studied a batch experimental system for removal of some toxic metals such as $\mathrm{Ni}$ (II), $\mathrm{Pb}$ (II), and $\mathrm{Cd}$ (II) using banana peel and food waste. The effects of various parameters were investigated and the maximum adsorbent amount found for $\mathrm{Pb}$ was $0.1 \mathrm{~g}$, for $\mathrm{Cd}$ and $\mathrm{Ni}$ it was $0.25 \mathrm{~g}$ (13). According to the results of another study (14), the removal of cadmium using hydroxyapatite as an adsorbent was studied in an aqueous system. Also, the experimental design methodology and the response surface methodology (RSM) were used to optimize some parameters such as $\mathrm{pH}$ and adsorbent dosage for the removal of cadmium. The RSM indi-

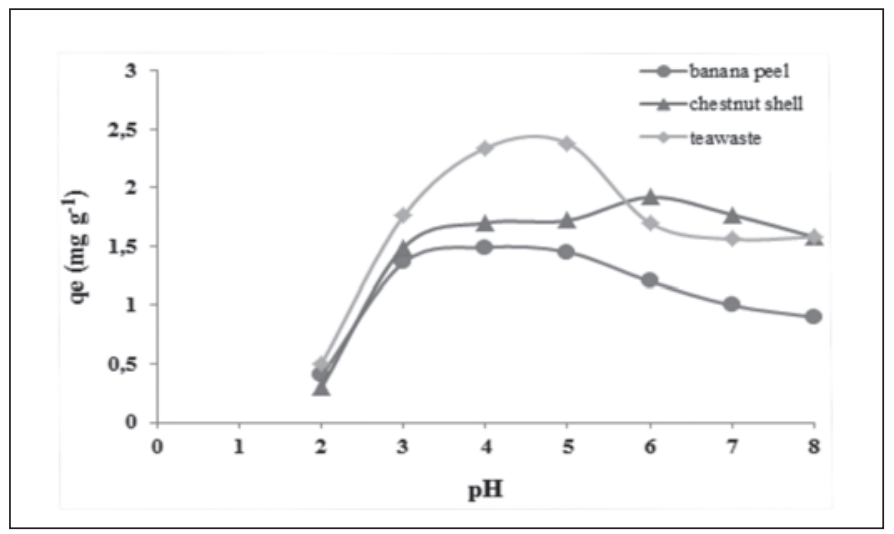

Fig. 1. Effect of pH on adsorption capacity of copper on banana peel, chestnut shell, and tea waste.

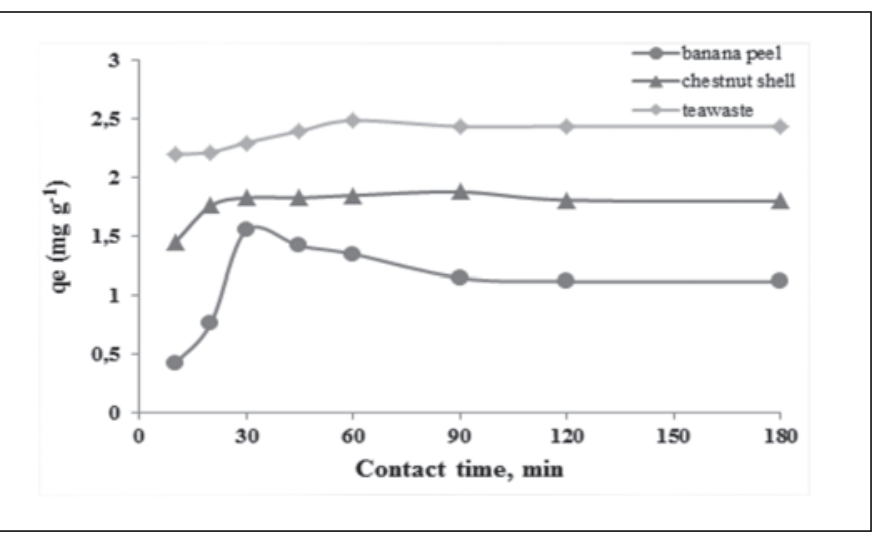

Fig. 2. Effect of contact time on adsorption capacity of copper on banana peel, chestnut shell, and tea waste. 
cated that the optimum adsorbent dosage of hydroxyapatite was $0.57 \mathrm{~g}$ for the adsorption of $\mathrm{Cd}(\mathrm{II})$.

\section{Effect of Final Volume}

The final volume of copper solution was also studied in order to determine the appropriate volume required for optimum adsorption of all adsorbents. For this step, the adsorbents were interacted with copper solutions but at different volumes (25-300 mL). All experimental parameter values including $\mathrm{pH}$ and contact time are listed in Table III.

Figure 4 shows the optimum final volume required for the adsorption capacity of these adsorbents. According to the obtained results, the solution volume has little effect on the adsorption capacity of the adsorbents. Adsorption capacities were about the same regardless of the difference in volume. The final volume for optimum adsorption capacity of banana peel was $50 \mathrm{~mL}$, for chestnut shell and tea waste it required $100 \mathrm{~mL}$.

\section{Calculation of Metal Concentration}

The amount of metal adsorption was calculated according to Equation 1 .

$$
\mathrm{q}_{\mathrm{e}}=\left(\left(\mathrm{C}_{0}-\mathrm{C}_{\mathrm{e}}\right) \times \mathrm{V}\right) / \mathrm{m} \quad \text { Eq. (1) }
$$

where $\mathrm{q}_{\mathrm{e}}$ is the amount of $\mathrm{Cu}$ (II) adsorbed by the natural adsorbents $\left(\mathrm{mg} \mathrm{g}^{-1}\right)$

$\mathrm{C}_{0}=$ The metal concentrations in the solution initial adsorption (mg L ${ }^{-1}$ )

$\mathrm{C}_{\mathrm{e}}=$ The metal concentrations in the solution after adsorption $\left(\mathrm{mg} \mathrm{L}^{-1}\right)$ (L)

$\mathrm{V}=$ The volume of the solution (g)

$\mathrm{m}=$ The mass of adsorbent used

The metal adsorption capacities of used natural adsorbents were calculated at optimum conditions. The $\mathrm{q}_{\mathrm{e}}$ was calculated as $1.94 \mathrm{mg} \mathrm{g}^{-1}$, $2.25 \mathrm{mg} \mathrm{g}^{-1}$, and $3.36 \mathrm{mg} \mathrm{g}^{-1}$ for banana peel, chestnut shell, and tea leaf waste, respectively. According to the obtained results, tea leaf waste has better absorption capacity than banana peel and chestnut shell.

\section{Atomic Mpectroscopy \\ 1 Vol. 38(5), Sept./Oct. 2017}

\section{Adsorption Isotherms}

The isotherms of adsorption are the data calculated at the equilibrium point of the adsorbent. Isotherms were represented as positive, smooth, and concave. The amount of toxic metals was increased with the equilibrium concentration of toxic metals in solutions and showed that $\mathrm{Cu}$ (II) had better adsorption on the tea leaf waste adsorbent than banana peel and chestnut shell. Because of the shape of the isotherms, the data of adsorption were calculated according to the Langmuir and Freundlich equations and are given in Equations 2 and 3.

$$
\begin{array}{ll}
\mathrm{q}_{\mathrm{e}}=\mathrm{K}_{\mathrm{F}} \mathrm{C}_{\mathrm{e}}^{1 / \mathrm{n}} & \text { Eq. (2) } \\
\frac{1}{\mathrm{q}_{\mathrm{e}}}=\frac{1}{\mathrm{~K}_{\mathrm{L}} \mathrm{Ce}}+\frac{1}{\mathrm{Q}_{\mathrm{m}}} & \text { Eq. (3) }
\end{array}
$$

where $\mathrm{q}_{\mathrm{e}}=$ The amount of toxic metals per unit weight of the adsorbents ( $\left.\mathrm{mg} \mathrm{g}^{-1}\right)$
TABLE III

Values of Optimum Parameters for $\mathrm{Cu}$ Adsorption

\begin{tabular}{lccc}
\hline Parameters & $\begin{array}{c}\text { Banana } \\
\text { Peel }\end{array}$ & $\begin{array}{c}\text { Chestnut } \\
\text { Shell }\end{array}$ & $\begin{array}{c}\text { Tea Leaf } \\
\text { Waste }\end{array}$ \\
\hline $\mathrm{pH}$ & 4 & 6 & 5 \\
Contact time (min) & 30 & 90 & 30 \\
Adsorbent amount $(\mathrm{g})$ & 0.5 & 0.25 & 0.25 \\
Final Volume of Solution $(\mathrm{mL})$ & 50 & 100 & 100 \\
\hline
\end{tabular}

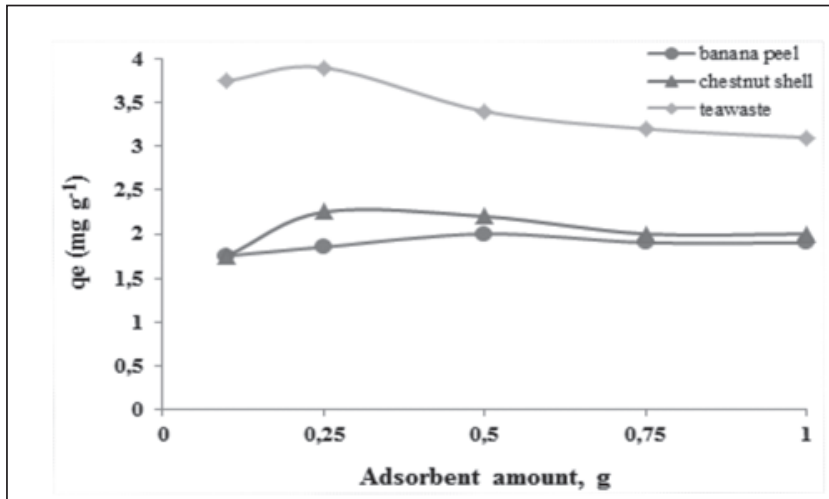

Fig. 3. Effect of adsorbent dose on adsorption capacity of copper on banana peel, chestnuts shell, and tea leaf waste.

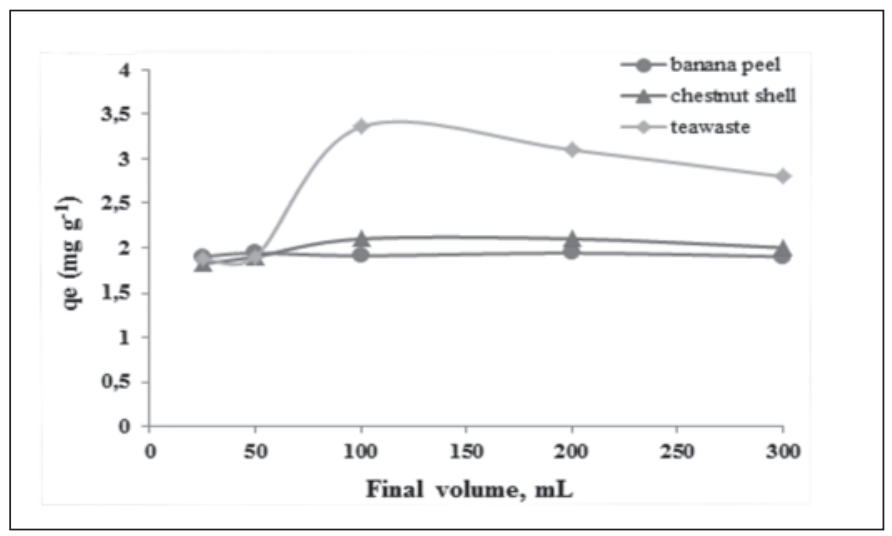

Fig. 4. Effect of final volume on adsorption capacity of copper on banana peel, chestnut shell, and tea leaf waste. 
$\mathrm{C}_{\mathrm{e}}=$ The equilibrium concentration of the copper $\left(\mathrm{mg} \mathrm{L}^{-1}\right)$

$\mathrm{K}_{\mathrm{F}}=$ Freundlich constant about adsorption capacity ( $\mathrm{mg} \mathrm{g}^{-1}$ )

$\mathrm{N}=$ Freundlich constant about adsorption intensity

$\mathrm{K}_{\mathrm{L}}$ = Langmuir constant about the intensity of the adsorption process $\left(\mathrm{L} \mathrm{mg}^{-1}\right)$

$\mathrm{Q}_{\mathrm{m}}=$ Constant relating to the surface area occupied by a monolayer of metals, reflecting the adsorption capacity ( $\mathrm{mg} \mathrm{g}^{-1}$ )

Based on the data of $\mathrm{q}_{\mathrm{e}}$ from the fittings of the pseudo-second order adsorption rate model, $\mathrm{Q}_{\mathrm{m}}$ and $\mathrm{K}_{\mathrm{L}}$ can be determined from its slope and intercept from a typical plot of $1 / \mathrm{q}_{\mathrm{e}}$ versus $1 / \mathrm{C}_{\mathrm{e}}$. In Equation 2 , the slope $1 / n$, ranging between 0 and 1 , is a measure for the adsorption intensity or surface heterogeneity. $\mathrm{K}_{\mathrm{F}}$ is a constant for the system, related to the bonding energy. $\mathrm{K}_{\mathrm{F}}$ can be defined as adsorption or distribution coefficient and represents the general capacity of toxic metals adsorbed onto the adsorbent for a unit equilibrium concentration. The results of the Freundlich and Langmuir isotherms fitted by using the data of adsorption capacity from the regression of Equation 3.

\section{FTIR Analysis of Adsorbents}

The functional groups possessed by the adsorbents indicate that the copper is bound to the surface of the adsorbents. In light of this information, observed changes and shifts in FTIR bands can be indicated by the dominance of the ion exchange over the $\mathrm{Cu}$ (II) sorption on adsorbents. For example, adsorption band at approximately $3330 \mathrm{~cm}^{-1}$ is attributable to the hydroxyl groups from the polyphenols originally present in all adsorbents. At the same time, the $\mathrm{C}-\mathrm{H}$ groups stretching vibrations can be seen at $2900 \mathrm{~cm}^{-1}$ (Figures 5a, 5b, and 5c). While the observed band around at $2851 \mathrm{~cm}^{-1}$ was assigned to the

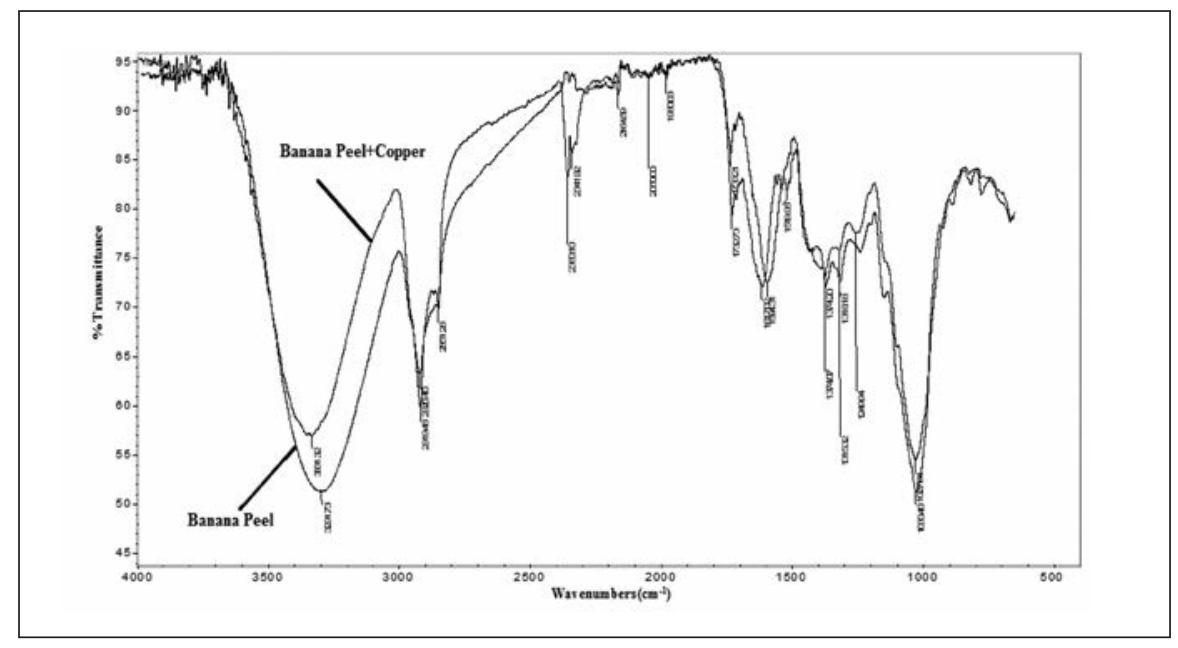

Fig. 5a. FTIR spectra of banana peel and Cu-loaded banana peel.

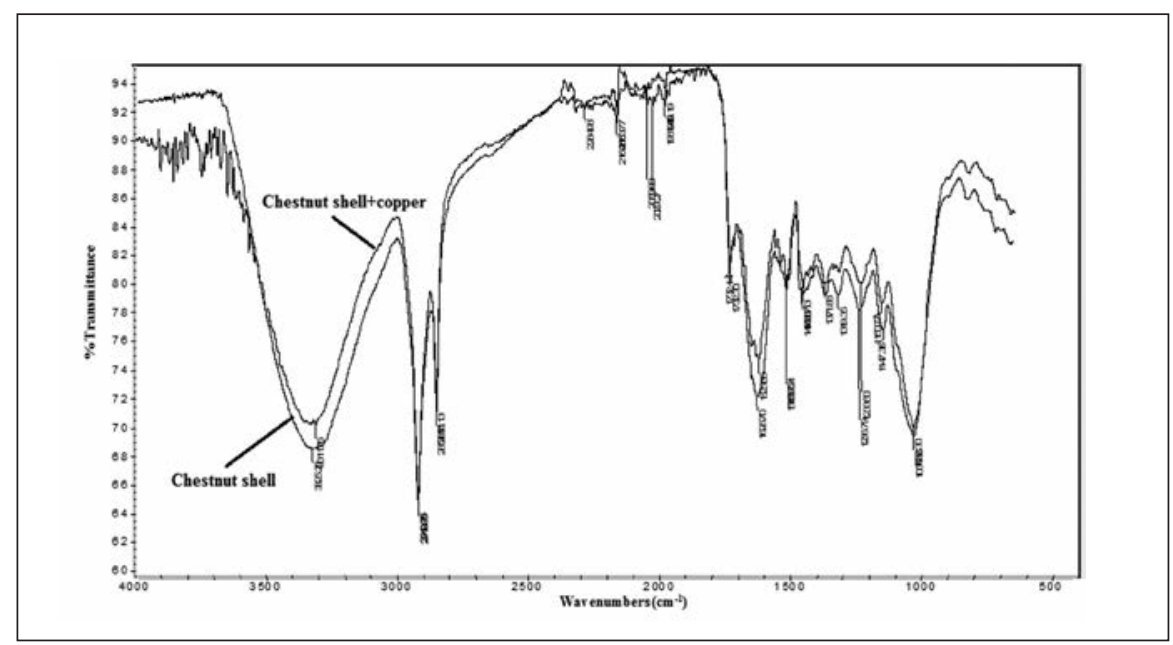

Fig. 5b. FTIR spectra of chestnut shell and Cu-loaded chestnut shell

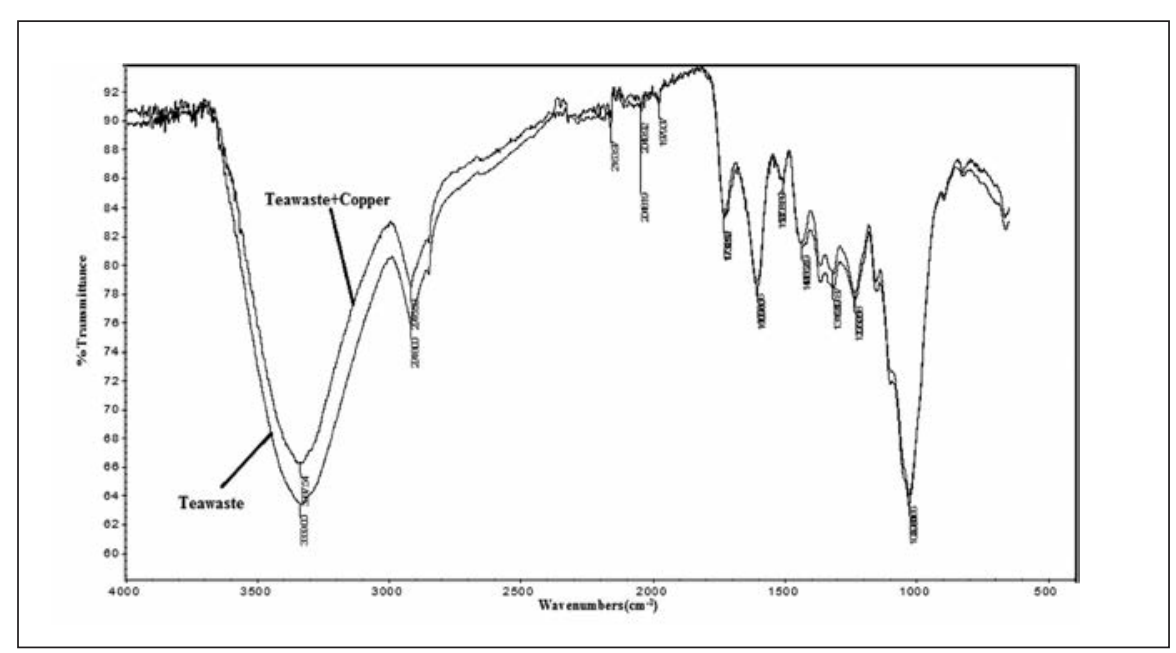

Fig. 5c. FTIR spectra of tea leaf waste and Cu-loaded tea waste. 


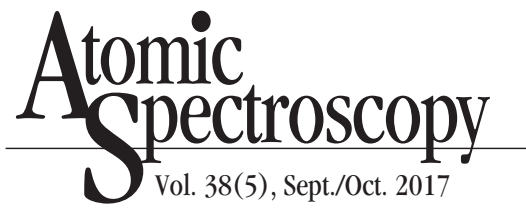

stretching vibration of the $\mathrm{C}-\mathrm{H}$ alkane groups, peaks around 1730 $\mathrm{cm}^{-1}$ indicates groups of carboxylic acid or its ester. Symmetric and asymmetric stretching of $\mathrm{C}=\mathrm{O}$ or $\mathrm{C}=\mathrm{C}$ aromatic vibrations were observed at peak around $1600 \mathrm{~cm}^{-1}$. At around $1625 \mathrm{~cm}^{-1}$ reflects carbonyl group stretching (amide). Figure 5 summarizes the shifts and changes in the FTIR bands, especially the ion exchange over the $\mathrm{Cu}(\mathrm{II})$ sorption on adsorbents.

\section{Application to Real Samples}

The developed analytical method was applied to natural mineral water samples besides some industrial wastewater samples under optimum conditions. The results obtained are listed in Table IV. The results show that concentrations of $\mathrm{Cu}$ in the mineral water and industrial wastewater samples were found in the range of $12.6 \pm 0.4-14.7 \pm 0.3 \mathrm{ng} \mathrm{mL}^{-1}$ and $42.6 \pm 1.2-116.0 \pm 2.3 \mathrm{ng} \mathrm{mL}^{-1}$, respectively. The accuracy of the method was studied by examining the standard reference material SPS-SW1 Batch 119 Surface waters (Spectrapure Standards AS, Oslo, Norway). The recovery of the standard additions study and the standard reference material was obtained as $98 \%$.

Kaplan Ince et al. (14) used the response surface methodology (RSM) with a quadratic model for the adsorption of cadmium from aqueous solution using hydroxyapatite. After optimized experimental conditions, optimal adsorption of Cd(II) was obtained as $895 \mathrm{mg} \mathrm{g}^{-1}$ (14). Chiban et al. (40) used a dried plant material in order to remove some heavy metals using the batch adsorption technique and attained about 99\% removal for $\mathrm{Pb}$ (40). Donga et al. (41) reported that hydroxyapatite/magnetite (HAp/ $\mathrm{Fe}_{3} \mathrm{O}_{4}$ ) was produced as a novel composite adsorbent for removing $\mathrm{Pb}$ from aqueous solution, and they removed $99 \%$ of the $\mathrm{Pb}(\mathrm{II})$ ions. Gupta et al. (42) reported a novel

TABLE IV

Cu Concentrations Determined in Real Samples in This Study (Tea Leaf Waste Results)

\begin{tabular}{|c|c|c|}
\hline Sample & $\begin{array}{l}\text { Concentration } \\
\left(\mu \mathrm{g} \mathrm{g}^{-1}\right)\end{array}$ & $\begin{array}{c}\text { Recovery } \\
(\%)\end{array}$ \\
\hline Mineral water 1 & $12.8 \pm 0.5$ & \\
\hline Mineral water 2 & $14.7 \pm 0.3$ & \\
\hline Mineral water 3 & $12.6 \pm 0.4$ & \\
\hline Mineral water 4 & $14.3 \pm 0.6$ & \\
\hline Industrial wastewater 1 & $42.6 \pm 1.2$ & \\
\hline Industrial wastewater 2 & $79.8 \pm 2.0$ & \\
\hline Industrial wastewater 3 & $116.0 \pm 2.3$ & \\
\hline Mineral water $2+30 \mathrm{ng} \mathrm{mL}^{-1} \mathrm{Cu}(\mathrm{II})$ & $42.4 \pm 0.5$ & 99 \\
\hline Mineral water $2+60 \mathrm{ng} \mathrm{mL}^{-1} \mathrm{Cu}(\mathrm{II})$ & $84.5 \pm 1.3$ & 98 \\
\hline Mineral water $2+90 \mathrm{ng} \mathrm{mL}^{-1} \mathrm{Cu}(\mathrm{II})$ & $104.2 \pm 2.2$ & 99 \\
\hline \multirow[t]{2}{*}{ Standard reference materials } & Certified 20.0 & \\
\hline & Found $20 \pm 1$ & 98 \\
\hline
\end{tabular}

The results are mean values \pm standart deviation, $n=3$.

carbon (RTAC) method as adsorbent for some heavy metals from aqueous solutions. They achieved around $96 \%$ for $\mathrm{Pb}$ and $87 \%$ for $\mathrm{Ni}$ removal by RTAC.

\section{CONCLUSION}

In the present study, a batch technique for the adsorption of $\mathrm{Cu}$ (II) has been carried out using banana peel, chesnut shell, and tea leaf waste as the adsorbent. Some important parameters for the batch technique such as $\mathrm{pH}$, contact time, adsorbent dose, and final volume were investigated for determining the different food waste adsorbents' adsorption capacities. According to the experimental results, tea leaf waste was found to be the best adsorbent for copper.

This study is also important in terms of employing used waste materials as adsorbent sources for removing heavy metals to prevent harm to humans and the environment. All performed adsorption experiments have shown that these adsorbents are effective for the removal of $\mathrm{Cu}$ (II) from industrial wastewaters and natural mineral waters.

\section{ACKNOWLEDGMENT}

This study was part of the project supported by Munzur University Scientific Investigations Project Unit (TUNIBAP- MFTUB014-01).

$\overline{\text { Received January 27, } 2017 .}$

\section{REFERENCES}

1. M.N.V. Prasad and H. Freitas, Environ. Pollut. 110, 277 (2000).

2. D. Özcimen and, A. ErsoyMericboyu, J. Hazard. Mater. 168, 1118 (2009).

3. M.M. Rao, A. Ramesh, G.P.C. Rao, and K. Seshaiah, J. Hazard. Mater. 129, 123 (2006).

4. S.E. Bailey, T.J. Olin, R.M. Brica and D.D. Adrian, Water Res. 33(11), 2469 (1999).

5. Y. Al-Degs, M.A.M. Khraisheh and M.F. Tutunji, Water Res. 35(15), 3724 (2001).

6. P.X. Sheng, Y.P. Ting, J.P. Chen, and L. Hong, J. Colloid Interface Sci. 275, 131 (2004). 
7. E. Malkoc and Y.Nuhoglu, J. Hazard. Mater. B127, 120 (2005).

8. M. Ince, At. Spectrosc. 35(5), 225 (2014).

9. S. Mohana, B.K. Acharya, and D. Madamwar, J. Hazard. Mater. 163, 12 (2009).

10. A.N. Bdour, M.R. Hamdi, and Z. Tarawneh, Desalination 237, 162 (2009).

11. Y. Sahin and A. Ozturk, Process Biochem. 40 (5), 1895 (2005).

12. D. Balkose and $\mathrm{H}$. Baltacioglu, J. Chem. Technol. Biotechnol. 54, 393 (1992).

13. M. Ince, O. Kaplan Ince, V. Yonten and N.M. Karaaslan, At. Spectrosc. 37(3), 125 (2016).

14. O. Kaplan Ince, M. Ince, N.M. Karaaslan, and V. Yonten, Anal. Lett. 49(15), 2513 (2016).

15. O. Kaplan Ince, M. Ince, V. Yonten, and A. Göksu, Food Chem. 214, 637 (2017).

16. A. Djukic', U. Jovanovic', T. Tuvic', V. Andric', J.G.

Novakovic', N. Ivanovic', and L. Matovic', Ceram. Int. 39(6), 7173 (2013).

17. A. Dabrowski, Adv. Colloid Interface. 93, 135 (2001).

18. J. Jaramillo, V. Gómez-Serrano, P.M. Álvarez, J. Hazard. Mater. 161, 670 (2009).

19. Z.-Y. Yao, J.-H. Qi, and L.-H. Wang, J. Hazard. Mater. 174, 137 (2010).

20. S. Kesraoui-Ouki, C. Cheeseman and R. Perry, Environ. Sci. Technol., 27, 1108 (1993).

21. S.J.T. Pollard, G.D. Fowler, C.J. Sollars, and R. Perry, Sci. Total Environ. 116, 31 (1992).

22. K. Wilson, H. Yang, C.W. Seo, and W.E. Marshall, Bioresource Technol. 97, 2266 (2006).
23. W.S.WanNgah and M.A.K.M. Hanafiah, Bioresource Technol. 99, 3935 (2008).

24. S. Wang and H. Wu, J. Hazard. Mater. 136, 482 (2006).

25. S. Wang, H.M. Ang, and M.O. Tadé, Chemosphere 72, 1621 (2008).

26. S. Wang and Y. Peng, Chem. Eng. J. 156, 11 (2010).

27. S. Babel and T.A. Kurniawan, J. Hazard. Mater. 97, 219 (2003).

28. J.L. Schonoor, Phytoremediation. TE-97-01, Groundwater Remediation Technologies Analysis Center, Pittsburg, PA, USA (1997).

29. A.K. Sengupta and D. Clifford, Environ. Sci. Technol. 20, 149 (1986).

30. M. Vaca Mier, R.L. Callejas, R. Gehr, B.E.J. Cisneros and P. Alvarez, Water Res. 35(2), 373 (2001).

31. C.P. Huang and D.W. Blankenship, Water Res. 18, 37 (1984).

32. J.S. Kwon, S.T. Yun, J.H. Lee, S.O. Kim, and H.Y. Jo, J. Hazard. Mater. 174, 307 (2010).

33. O.S. Amuda and A.O. Ibrahim, Afr. J. Biotechnol. 5, 1483 (2006).

34. A.H. Mahvi, D. Naghipour, F. Vaezi, and S. Nazmara, Am. J. Appl. Sci. 2, 372 (2005).

35. N. Rajic, D. Stojakovic, M. Jovanovic, N. Zabukovec Logar, M. Mazaj, and V. Kaucic, Appl. Surf. Sci. 257, 1524 (2010).

36. Z.Y. Yao, J.H. Q, and L.H. Wang, J. Hazard. Mater. 174, 137 (2010).

37. M. Jiang, X. Jin, X. Lu, and Z. Chen, Desalination 252, 33 (2010).

38. A. Zuorro and R. Lavecchia, Am. J. Applied Sci. 7, 153 (2010).

39. F.Y Wang, H Wang, and J.W.
Ma, J. Hazard. Mater. 177, 300 (2010).

40. M. Chiban, A. Soudani, F. Sinan, S. Tahrouch, and M. Persin, Clean-Soil, Air, Water 39(4), 376 (2011).

41. L. Donga, Z. Zhua, and Y. Qiub, J. Zhoa, J. Chem. Eng. 165, 827 (2010).

42. V.K. Gupta, M.R. Ganjali, A. Nayak, B. Bhushan, and S. Agarwal, Chem. Eng. J. 197, 330 (2012). 